BOGDAN KLEPACKI

Warsaw University of Life Sciences, Poland

bogdan_klepacki@sggw.edu.pl

ORCID iD: 0000-0003-3483-7530

SCOPUS iD: 57213417527

KONRAD MichalSKI

Warsaw University of Life Sciences, Poland

konrad_michalski@sggw.edu.pl
Barbara Kusto

Jan Kochanowski University of Kielce, Poland barbara.kusto@ujk.edu.pl

ORCID iD: 0000-0001-6848-2569

JAKUB ZAŁUSKI

Warsaw University of Life Sciences, Poland jakubz5@onet.pl

\title{
THE IMPORTANCE OF CARSHARING AS A WAY OF TRAVELING AROUND THE CITY
}

\section{ZNACZENIE CARSHARINGU JAKO SPOSOBU PRZEMIESZCZANIA SIĘ W OBRĘBIE MIASTA}

\begin{abstract}
It is becoming increasingly important for individuals to be able to access goods without owning them. This applies to various resources, including cars, which have become an integral part of many people's lives. Thus, companies enabling short-term vehicle rental were established. One of the forms is automobile rental priced e.g. by the minute called carsharing. This solution has become increasingly popular around the world for over a dozen years, and since 2016 it has also been available in Poland.
\end{abstract}


The research presented in this paper examines the functioning of companies offering carsharing services in Poland. The study involved a survey exploring the usage of various means of transport to get around the city. To conduct the empirical research, a number of companies offering carsharing services, namely Traficar, Panek CarSharing, and 4Mobility Carsharing, were purposefully sampled. The research was conducted in 2020. The survey included 126 randomly selected residents of the Warsaw Metropolitan Agglomeration. The research shows that e-carsharing schemes are still not very common, as only a small percentage of the respondents declared using such services. People using shared cars usually rent them for short journeys, and their expenditure on this type of transport is relatively low. The main conclusion from this research is that carsharing services, deriving from the idea of sharing economy, have growth potential, and their further development requires complementary actions to be taken, inter alia, on the part of the owners of urban infrastructure (mainly parking spaces).

\section{STRESZCZENIE}

Coraz większe znaczenie ma możliwość dostępu do dóbr bez ich posiadania. Dotyczy to wielu produktów, w tym samochodów, które stały się nieodłącznym elementem życia wielu ludzi. Powstały więc firmy umożliwiające krótkookresowe wypożyczanie pojazdów. Jedną z form jest wypożyczenie auta, np. na minuty, zwane carsharingiem. Takie rozwiązanie zdobywa od kilkunastu lat coraz większą popularność na świecie, a od 2016 roku rozwija się również w Polsce.

W opracowaniu postawiono za cel rozpoznanie funkcjonowania przedsiębiorstw oferujących usługi współdzielenia pojazdów w Polsce. Przeprowadzono badanie ankietowe dotyczące wykorzystania środków transportu w celach przemieszczania się w obrębie miasta. Do przeprowadzenia badań empirycznych, w sposób celowy przyjęto przedsiębiorstwa oferujące usługi typu carsharing, a mianowicie Traficar, Panek CarSharing oraz 4Mobility Carsharing. Badania empiryczne oraz ankietowe przeprowadzono w roku 2020. Badaniami ankietowymi objęto 126 osób dobranych w sposób losowy, spośród mieszkańców aglomeracji warszawskiej. W wyniku badań stwierdzono, że e-usługi carsharingu są jeszcze mało rozpowszechnione, gdyż tylko niewielki odsetek badanych korzystał z takich usług. Osoby korzystające ze współdzielonych samochodów wynajmują je do przejazdów na krótkich dystansach, a w ich budżecie wydatki na ten typ transportu stanowią stosunkowo niewielką kwotę. 
Głównym wnioskiem z badań jest to, że usługi carsharingu, na bazie idei gospodarki współdzielenia, mają potencjał rozwojowy, a ich dalszy rozwój jest uzależniony od szeregu komplementarnych działań także ze strony właścicieli przestrzeni miejskich (przede wszystkim miejsca parkingowe).

KEYWORDS: sharing economy, collaborative consumption, carsharing, city transport, passenger transport

SŁOWA KLUCzowe: ekonomia współdzielenia, wspólna konsumpcja, car sharing, transport miejski, przewóz osób

\section{INTRODUCTION}

Nowadays, the ability to access goods when they are needed rather than owning them is becoming more and more valued solution. The essence of the sharing economy and its benefits are increasingly recognized. Although the first initiatives to share goods took place in the first half of the twentieth century, the sharing economy was first mentioned in the literature by Marcus Felson and Joe L. Spaeth in the late 1970s. The most dynamic development of the sharing economy began at the end of the 20th and beginning of the 21st century and continues to this day (Zgiep, 2014). Undoubtedly, the widespread Internet use and the development of social networking sites and digital platforms have had a considerable impact on the dissemination of this idea (Ziobrowska, 2017). Leveraged by the information technology, the sharing economy encompassed further sectors of human activity, including, inter alia, the means of transport. Due to the fact that a car is an inseparable part of many people's lives, new automobile rental services were created to make cars available for rent when there is a need to travel. One of the possible schemes is a short-term car rental, e.g. priced by the minute, called carsharing. This solution has become increasingly popular around the world for over a dozen years, and since 2016 it has also been developing in Poland (Kubera, 2018). The aforementioned form of vehicle rental enables the reduction car maintenance costs and allows the user to plan expenses, because the fare for using a shared car is calculated in advance (Larisch, 2014). Moreover, taking into account that one shared car can replace several privately owned cars and the fact that many of the 
shared vehicles are environmentally friendly, carsharing may have a significant impact on reducing the emission of harmful gases into the atmosphere. The aforementioned factors lead to the conclusion that carsharing is in tune with the concept of sustainable development, which is increasingly promoted and included in business development strategies (Zgiep, 2014).

The main goal of the current study is to broaden the knowledge about the sharing economy and examine the functioning of the carsharing services and their providers in Poland. The study involved a survey exploring the usage of various means of transport to get around the city of Warsaw. It also examines the functioning of carsharing schemes and operations of companies offering such services. In addition, the study seeks to address the following specific objectives: to recognize practical applications of the sharing economy and determine how users perceive carsharing services.

Due to the prospects for the dynamic development of all types of rental and sharing services, as well as the progressive change of attitudes from the need to own to the need to access a given good, the research focused on companies offering carsharing services, namely Traficar, Panek CarSharing and 4Mobility Carsharing,. The empirical research and the survey were conducted in 2020. The survey sample included 126 randomly selected residents of Warsaw Municipal Agglomeration.

\section{RESEARCH METHODS}

Various methods were used to conduct the research presented in this paper. The stage of collecting research material involved a literature review, a survey and mass statistics data analysis. At the stage of processing the collected materials two analyses were conducted - a horizontal analysis, aimed at comparing the situation of the carsharing industry in Poland and other countries, and the analysis of the dataset collected from the survey. To present the research results descriptive, tabular and graphical methods have been used. 


\section{GENESIS OF THE SHARING ECONOMY}

When in 1978, in a study on the structure of community and consumption based on collaboration, Marcus Felson and Joe L. Spaeth addressed topics related to sharing access to goods, they called the idea of the sharing economy "the collaborative consumption", which was defined as "events in which goods and items are shared conjointly between people through several joint activities" (Felson \&Spaeth, 1978). In practice, the phenomenon of sharing goods can be observed in Western Europe since around 2008, while in Poland - since 2010. During this period, the attitude assuming that it is better to have access to goods rather than own them has been spreading. Additionally, the widespread Internet use, including social media as well as increasing access to mobile devices, facilitated communication between people who began to cooperate by swapping, borrowing, lending and sharing their resources with others. These types of activities were an effective way of saving money and coping with the financial crisis (Ziobrowska, 2017).

When considering the sharing economy, it is necessary to explain what this term really means. Matofska (2016) defined it as a socio-economic ecosystem based on the joint use of human, material and intellectual resources, which includes the joint creation, production, distribution, as well as trade and consumption of goods and services by various people and organizations. This system includes, among others: all kinds of exchanges and swaps, borrowing, lending, co-ownership, co-creation, collective purchasing, collective consumption, recycling, re-selling and purchasing used goods, as well as services based on the subscription model and the pay-as-you-go model, where charges are based on usage. The word "sharing" refers to the using and accessing common resources but does not exclude money exchange, because the sharing economy is a hybrid economy which encompasses various forms of value exchange (Matofska, 2016). The phrase "sharing economy" should be translated into Polish as "gospodarka współdzielenia". There are also the terms "on-demand economy", "collaborative economy” or „peer economy” which are incorrectly equated with the "sharing economy". The correct replacement term may be "collaborative consumption", which means shared consumption (Malinowski, 2016). 
The PwC's report shows the five key sectors where sharing economy applies, namely: travel, car sharing, finance, staffing, and music and video streaming. In 2015, the global revenue of these sectors amounted to approximately USD 15 billion, while PwC's projections show that revenues in 2025 will reach USD 335 billion, which means over 20 -fold growth over 10 years. The reason for such growth forecasts may be the increasing interest in enterprises that fit into the framework of the sharing economy (PwC, 2015).

According to Poniatowska-Jaksch (2016), two of the atomic business models proposed by Peter Weil and Michael R. Vitale [2001) are best applied in the sharing economy, namely - "Direct to Customer" model and "Intermediary" model. The distinguishing feature of the former is direct communication between providers and consumers; while in the latter the communication between providers and consumers is facilitated by intermediaries who concentrate information e.g. agents, digital platforms, auction portals etc. For many people, the peer-to-peer ( $\mathrm{P} 2 \mathrm{P})$ communication system, which assumes equal rights of both parties of the transaction and allows clients to play the role of traders, may be a novelty. This solution may provide additional income generated in spare time or through part-time activity as opposed to a fulltime job. In summary, the business model most characteristic for the sharing economy would be a combination of the two aforementioned models - "Direct to Customer" and "Intermediary" (Poniatowska-Jaksch, 2016).

\section{History OF CARSHARING AND PASSENGER TRANSPORT SERVICES}

Solutions similar to today's carsharing date back to 1948 when the Sefage cooperative began operating in Zurich. Under this scheme people who could not afford their own car could use the vehicle together with other interested parties (Becker et al., 2015). In the following years, various initiatives related to the "public car" emerged, such as the Procotip, which was launched in 1971 in France (Shaheen et al., 1998), and the Witkar, founded in 1968 in the Netherlands. Other initiatives in Europe included, among others: Mobility Carsharing in Switzerland, launched in 1987, or StattAuto, 
founded in 1988 in Berlin. In 1991, the European Car Sharing (ECS) association was founded to support lobbying efforts for temporary car rental services (Shaheen et al., 1998).

In the USA, the first carsharing projects date back to 1980s. This phenomenon began with the Mobility Enterprise program, which operated from 1983-1986 as a research program at Purdue University. Under this scheme very household that rented a small car from this company for a daily travel got access to a shared fleet of special vehicles for special tasks, such as limousines, off-road or leisure activity vehicles. In December 1983, STAR was founded in San Francisco, renting vehicles for periods starting from a few minutes to several days to people living in an apartment complex near San Francisco State University. STAR ceased operations in March 1985 (Shaheen et al., 1998). Today, there are several dozen companies in the US offering vehicle share services.

The history of carsharing in Poland began in October 2016, when the company Traficar began operating in Krakow. The offered vehicles were available for rental in the free-floating system. One year after entering the market, the company offered services in Kraków, Warsaw, Poznań, Wrocław and Gdańsk (Kubera, 2018). Also in 2016, 4Mobility entered the market and became the first carsharing service provider in Warsaw; however, it offered only a roundtrip rental (Olejniczak and Mendakiewicz, 2018). In April 2017, PANEK launched its services - the first company in Poland that offers users ecological hybrid cars (Michalski et al., 2019). Half a year later, the Vozilla company started operating in Wrocław and was the first company in Poland to offer fully electric cars for rent paid by the minute. They were available in the free-floating system. Additionally, bus lanes could be used by users of ecological vehicles offered by this company (Kubera, 2018).

The car sharing service is accessed via a mobile application and provides vehicles for rent. However, unlike traditional rental companies, the car does not have to be dropped off at the pick-up location (Olejniczak and Mendakiewicz, 2018) as it depends on the system in which the company operates. According to Larisch (2014), we can distinguish three variants of the functioning of a carsharing scheme:

- $\quad$ roundtrip carsharing, where the cars are picked up and dropped off at the same location, 
- free-floating carsharing, where the car can be picked up and drop off anywhere within the company's operating zone,

- $\quad$ peer-to-peer carsharing, where privately owned vehicles are offered for rent.

The charges for renting a shared car are calculated on the basis of the trip duration (by the hour or by the minute), which includes driving and stopping time, and in some cases it also includes by-the - kilometer rate. The vehicle can be booked by phone, via a mobile application or a website. All costs related to the maintenance of the car, such as fuel, insurance, parking fees, cleaning etc. are covered by the company providing the service (Larisch, 2014).

As Kubera (2018) notes, carsharing is a way to efficiently and quickly get around the municipal agglomeration, which is an alternative to city public transport, taxis, and can also replace owning a car. A significant convenience is the ability to end the trip and drop off the car at any location within the city. In addition, vehicles provided in carsharing schemes are new and have various amenities, such as air conditioning or a bluetooth.

Car sharing services are most often provided in large municipal agglomerations and places with high population density (Olejniczak and Mendakiewicz, 2018), however, there are exceptions - e.g. in Austria or Switzerland carsharing services are also available in smaller towns (Larisch, 2014). According to Larish, the distance limit to cost-effective usage of carsharing services was calculated at 11,250 km per year. Above this mileage, it is more economic to own a car. Therefore, the carsharing schemes are aimed mainly at people who need a car occasionally and irregularly, and who travel less than 10,000 $\mathrm{km}$ per year. The second target group may be businesses that do not need to use company cars on a daily basis. Carsharing is also dedicated to students who have mobility needs and often cannot afford to own a car. Therefore, some companies make special weekend offers dedicated to this group of users (Larisch, 2014). The advantages and disadvantages of carsharing are presented in Table 1. 
Table 1.

Advantages and disadvantages of carsharing services

\begin{tabular}{|l|l|}
\hline \multicolumn{1}{|c|}{ Advantages } & \multicolumn{1}{c|}{ Disadvantages } \\
\hline $\begin{array}{l}\text { Transparent rental charges that allow the } \\
\text { user to plan the expenses }\end{array}$ & Limited availability of vehicles \\
\hline $\begin{array}{l}\text { No costs of car maintenance, parking, } \\
\text { fuel (included in the price of the service) }\end{array}$ & $\begin{array}{l}\text { Possible limitation to independence and flexibility } \\
\text { due to the lack of a free vehicle at the time }\end{array}$ \\
\hline No cost of buying a car & $\begin{array}{l}\text { User registration, logging in and verification may } \\
\text { take a long time }\end{array}$ \\
\hline $\begin{array}{l}\text { Possibility to drive new vehicles from } \\
\text { different manufacturers }\end{array}$ & $\begin{array}{l}\text { Offers for businesses are not economically } \\
\text { attractive }\end{array}$ \\
\hline Greater mobility & Market penetration is too low \\
\hline
\end{tabular}

Source: based on Larisch (2014).

Carsharing is valued because it improves transportation, increases the availability of cars and meets the increasing requirements of customers (Kubera, 2018). It can be a way to solve the problem of traffic congestion in cities as it is estimated that one share vehicle can replace up to a dozen private vehicles (Janczewski, 2015). The greatest demand for these services is in Asia, especially in China, where such solutions are encouraged in order to combat poor air quality. When it comes to Europe, Germany has the highest number of vehicle-sharing services, followed by Italy, the Netherlands, Belgium, France and the United Kingdom. No carsharing initiatives were reported at the time in Greece and Cyprus (STARS, 2018).

Taxis, understood as vehicles powered by electric or internal combustion engines, were popularized at the end of the 19th century. Electric automobiles began to be used as taxis in New York in 1897 and replaced the then used carriages (Magazyn Kaszuby, 2019). In the same year, the first gas-powered taxis with a taximeter invented in 1891 appeared on the streets in Stuttgart. In Poland, the first taxi services appeared in 1900 in Warsaw, but they disappeared with the outbreak of World War I, only to return in the 1920s. A big innovation was the telephone and radio system introduced in the mid-1970s by the Miejskie Przedsiębiorstwo Taksówkowe in Warsaw, which made it possible to order a taxi by phone to the given address which also enabled more effective distribution of available vehicles. 
These types of systems remained in use for over 30 years, and then were superseded by the progressive digitization using more modern mobile devices and new digital platforms enabling booking trips via the Internet or smartphone applications. In 2012, iTaxi was created, the first Polish application for connecting passengers with licensed taxi drivers. A year later, MyTaxi was the first to introduce the option of mobile payment for the trip. In 2014, the American company Uber (Mazur et al., 2018) started operating in Poland introducing a mobile application for booking car rides with a driver (Sylwestrzak, 2018, p. 141).

MyTaxi, founded in 2009 in Hamburg, was the first operator to offer a mobile application to connect passengers with licensed taxis nearby. Another innovation introduced in 2013 was the possibility of cashless payment for the ride via an application, which increased the comfort and speed of transactions. Interestingly, the first in Europe ride-sharing service was launched in Warsaw in 2017, Passengers traveling in the same direction could share a taxi which reduced travel costs, harmful emissions and traffic as well as disseminated the idea of the sharing economy (Mazur et al., 2018). At the beginning of 2021, the operations of Uber or Bolt intermediary platforms were legally regulated. From January 2021 people using these services have to driven by licensed drivers in vehicles marked in accordance with the requirements set out in the appropriate regulations (BusinessInsider, 2020).

In July 2019, MyTaxi changed its name to FreeNow (Sieńko, 2019). The company offers the possibility of booking a ride in several variants (the cheapest, the closest available taxi, a vehicle of a higher standard, electric/ hybrid vehicle, van for more than 4 people), booking a taxi up to 4 days in advance, tracking and sharing the route with others, the possibility of rating drivers and adding them to favorites, as well as setting up a company account that provides a report of employee's journeys. The above-mentioned services are available in 9 countries in about 100 European cities (AppStore, 2021). In addition, in three countries, FreeNow offers the possibility to rent electric scooters, and in Germany also cars and scooters paid by the minute. In sum, FreeNow offers its services in 17 markets in 150 cities around the world, while by 2030 it plans to be the first mobility platform to achieve zero emissions in Europe (FreeNow, 2021). 
Uber is a company founded in 2009 in San Francisco, offering a mobile application that connects people looking for transport with drivers (Stępnicka, 2018, p. 490). In Poland, the company has been operating since 2014 and initially did not require the drivers to have the appropriate license to perform passenger transport (Polish law already requires it effective from January 2021) or a taximeter. The fare is calculated automatically by the app based on the distance and estimated travel time. Transportation services mediated by the company may be provided only by self-employed persons [Sylwestrzak, 2018, pp. 141-142). The platform allows the user to book a ride in the nearest available vehicle (UberX), a ride in a higher standard, Premium class cars (Uber Black) and a ride for a group of up to 6 people (UberXL). Through the application, you can also share the route, evaluate the driver after the completed course or leave a tip using mobile payments (AppStore, 2021a). The platform operates in over 10,000 cities in 69 countries around the world. In Poland the services are available in Warsaw, Wrocław, Gdańsk, Radom, Poznań, Lublin, Łódź, Kraków, Częstochowa and Silesia (Uber, 2021).

\section{Charakterystics OF RESPONDENTS}

The survey questionnaire was developed in order to identify the mobility patterns of the residents of the Warsaw Metropolitan Agglomeration and to determine how carsharing users perceived the services. The ComputerAssisted Web Interviewing (CAWI) method was used to conduct the survey on January 10 - February 8, 2021. The survey was made available on one of the social networking sites in groups dedicated to the residents of Warsaw and the surrounding towns and portals intended for the residents of the Warsaw Metropolitan Agglomeration. The sample included 126 randomly selected individuals, 34 of whom met the participation criteria for the questionnaire part concerning the use of carsharing services.

The sample included 72 women (57\% of all respondents) and 54 men. There were 83 people aged 18-25 (66\%), 29 - aged 26-40, 10 - aged 41-60, and 4 respondents over 60 years of age. About $57 \%$ of the respondents had higher education, $26 \%$ secondary education, $4 \%$ basic vocational education, and $13 \%$ 
primary education. As for the place of residence - 38\% of the respondents lived in rural areas, $13 \%$ - in cities up to 50,000 inhabitants, $18 \%$ - in cities of 50,000-150,000 inhabitants, $2 \%$ in cities of $150,000-500,000$ inhabitants, while $29 \%$ lived in cities with population over 500,000. 111 respondents $(88 \%$ of the sample) had a full driving license (B category).

\section{RESPONDENTS' TRANSPORTATION PREFERENCES}

In the survey, the respondents were asked about their transportation preferences and the related expenses. The issues of using car sharing services, their availability, rental duration and popularity of companies offering such services were also explored. One of the questions was to examine the frequency of using various means of transport available in the city. The answers are presented in Figure 1.

Figure 1.

Means of transport preferred by the respondents to get around the city

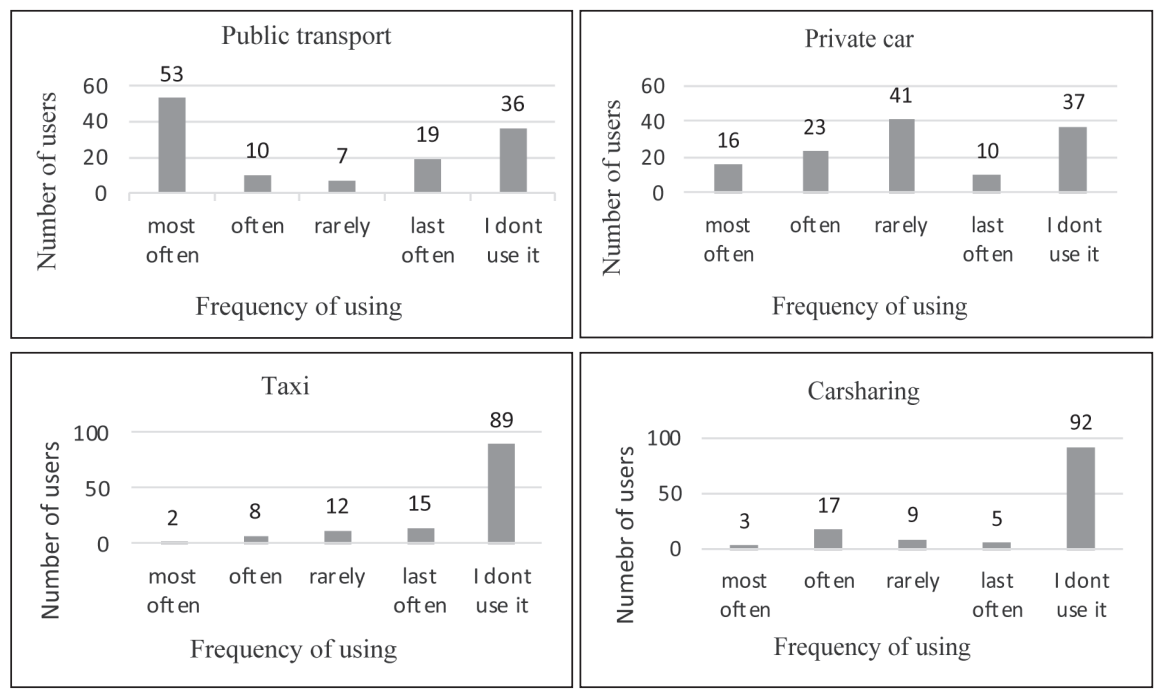




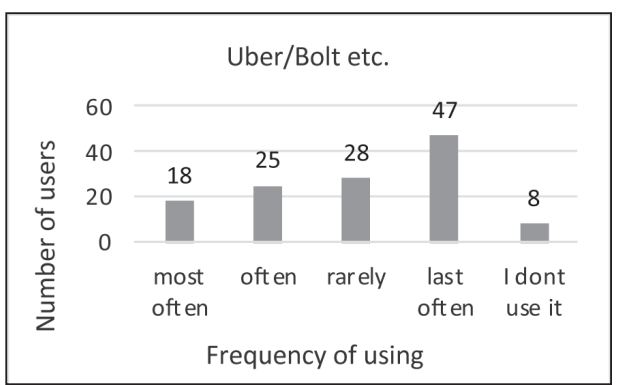

Source: own research.
The respondents most often used public transport, followed by private cars. Surprisingly, a relatively big share of respondents did not use taxi services. Similarly, carsharing services were not popular. In the case of car rides with a driver booked via applications such as Uber or Bolt, a large variation in the frequency of using this type of service could be noticed; however, this means of transport was used more often than taxi or carsharing services.

The respondents were also asked about the average monthly expenses on various types of transport. Most often, the expenses on city public transport did not exceed PLN 50 (48\%), only 4\% of the respondents spent PLN 150 a month. On the other hand, of those who traveled in their own car only $6 \%$ spend up to PLN 50 a month while 45\% spend over PLN 150 (usually PLN 150-300 - 34\%). The taxi service users most often spent up to PLN 50 per month, however $71 \%$ of the respondents did not use taxis at all. It was similar in the case of carsharing services - 14\% of users spent up to PLN 50 per month on this type of services, $10 \%$ - in the range of PLN 50-150 and 3\% - PLN 150-300. 73\% of the surveyed declared that they did not use carsharing services. As for the expenses on car rides with a driver booked via Uber or Bolt applications, most respondents spent up to PLN 50 per month.

Summarizing this part of the study, it can be noted that the most frequently used means of transport to travel around the city is public transport, which costs the users up to PLN 150 per month. The second most popular type of transport used in the city turned out to be rides with drivers booked via Uber, Bolt or FreeNow applications. Such popularity may be due to the affordable prices of the trips and the convenience of use, as the passenger is picked up directly from the current location and driven to the destination. The survey also shows that private cars are moderately used as a means of urban transport and the operating expenses of using this type of transport are quite high. Finally, the survey revealed low popularity of taxi and carsharing services. It can be assumed that currently taxi and vehicle-sharing services are only used for occasional short-distance trips. 


\section{THE RESPONDENTS' USAGE OF CARSHARING SERVICES}

The next part of the survey concerned carsharing services and the operations and popularity of carsharing organizations. The aim was also to determine how users perceived the service. The sample included 34 people $(27 \%$ of all respondents who took part in the survey), who declared that they used carsharing services. At this point, it is worth noting that $60 \%$ of all respondents declared that they were familiar with carsharing but did not use the service.

Of those using carsharing services, $15 \%$ declared that they use them several times a week, $44 \%$ - several times a month, while the remaining $41 \%$ use this type of services several times a year. The vast majority of respondents (82\%) stated that shared cars are easily available, while in the opinion of $18 \%$ it is difficult to access a vehicle. As for the trip duration, the most frequently declared periods included 15 to 30 minutes $-44 \%$ of the users and up to 15 minutes $-32 \%$ of users. None of the respondents declared trips longer than a day, which may be due to unfavorable rates discouraging users from renting cars for longer periods. The obtained results show that in the carsharing schemes, cars are mainly used for short journeys.

Additionally, the respondents were asked about the reasons for using shared cars. The sums of votes gained by each of the reasons are presented in Figure 2.

Figure 2.

Reasons for using carsharing services declared by the respondents

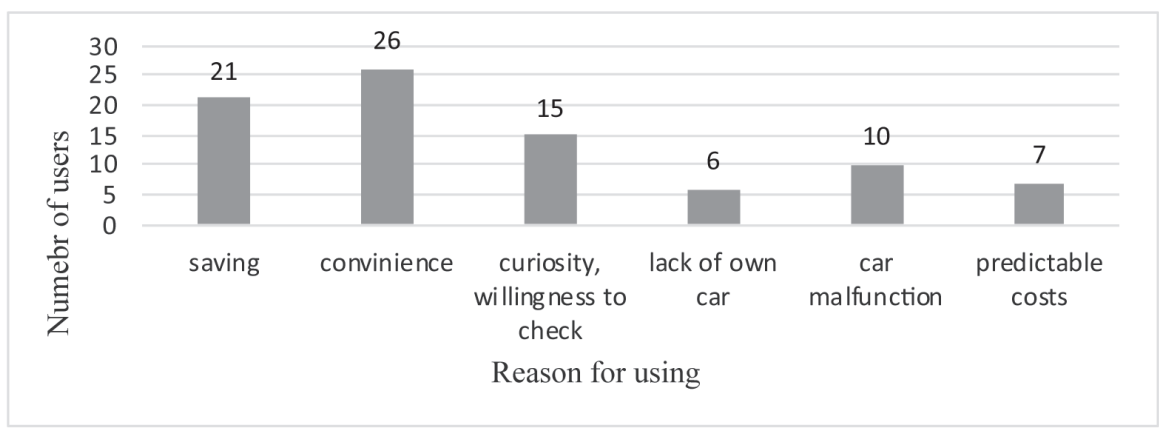

Source: own research. 
Most often, carsharing services were chosen for convenience, followed by economic reasons, but also curiosity, willingness to have a test drive and find out more about the service. For 10 respondents (7.9\%), the motivation to use shared cars was the failure of their own vehicle, while $5.6 \%$ of respondents appreciated the predictability of costs. The least frequently declared reason for using shared vehicles was the lack of one's own car. The preferences of users regarding organizations offering carsharing services were also examined. The respondents were asked to indicate the company whose services they used most often. The answers are presented in Figure 3.

Figure 3.

\section{Respondents' preferences regarding carsharing service providers}

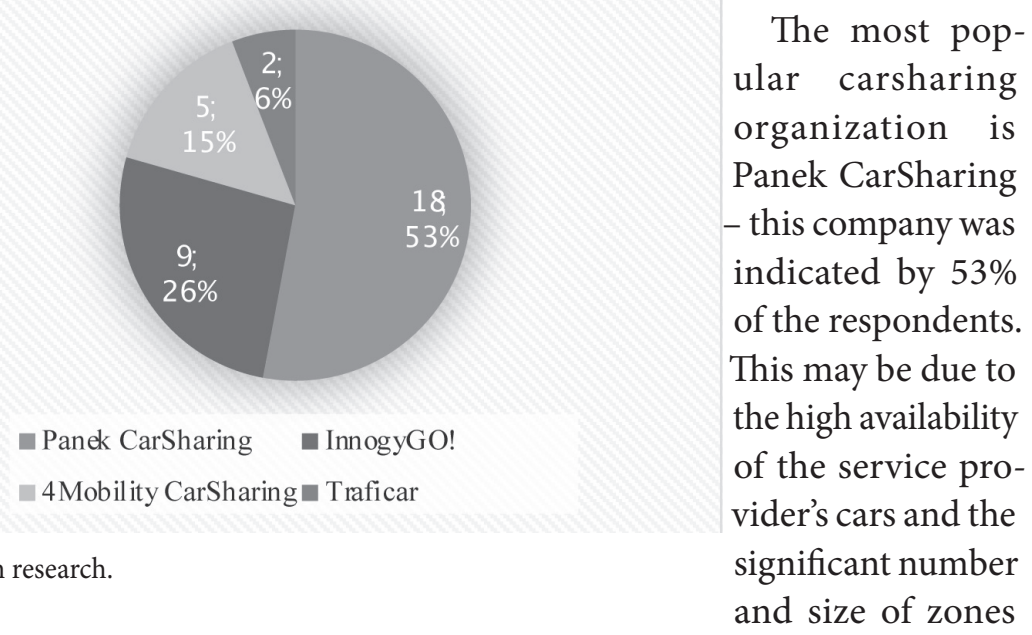

where vehicles can be picked up and dropped off. The second most popular service provider was InnogyGO! indicated by $26 \%$ of the surveyed. What attracts users to this organization may be the fact that their fleet consists of modern and dynamic BMW cars that are fully electric, and therefore - environmentally friendly. However, the service requires the user to pick up and drop off the car within defined zones in Warsaw, which may be a limitation for some users. About $15 \%$ of respondents chose 4 Mobility CarSharing as the one they use most often, while 2 people indicated the services offered by Traficar. 


\section{Advantages AND DisAdVANTAges OF CARSHARING}

In the last part of the survey, the respondents were questioned about the advantages and disadvantages of carsharing. On the basis of the obtained answers, Table 2 was created. Additionally the respondents were asked to indicate these aspects of the service which need to be changed or improved.

Table 2.

Advantages and disadvantages of carsharing indicated by the respondents

\begin{tabular}{|l|l|}
\hline \multicolumn{1}{|c|}{ Advantages } & \multicolumn{1}{c|}{ Disadvantages } \\
\hline Speed and convenience of travel & Limited vehicle pick-up and drop-off zones \\
\hline High availability of cars & $\begin{array}{l}\text { Possible lack of vehicle availability at a specific } \\
\text { time and location }\end{array}$ \\
\hline Free parking in paid parking zones & $\begin{array}{l}\text { Lack or insufficient number of parking spaces } \\
\text { dedicated to shared vehicles }\end{array}$ \\
\hline $\begin{array}{l}\text { A fleet of new models of different car } \\
\text { brands }\end{array}$ & $\begin{array}{l}\text { Shared vehicles are usually available in the } \\
\text { lowest trim levels }\end{array}$ \\
\hline $\begin{array}{l}\text { No need to own a car and no costs associ- } \\
\text { ated with it }\end{array}$ & $\begin{array}{l}\text { Confusing instructions on how to open, start, } \\
\text { close the vehicle and start or end a rental }\end{array}$ \\
\hline $\begin{array}{l}\text { Possibility to access a vehicle in an emer- } \\
\text { gency situation }\end{array}$ & $\begin{array}{l}\text { A high amount of the deposit is blocked for the } \\
\text { duration of the use of the vehicle }\end{array}$ \\
\hline $\begin{array}{l}\text { Possibility to estimate the travel cost, pre- } \\
\text { dictability of costs }\end{array}$ & $\begin{array}{l}\text { High cost of use in peak period traffic (traffic } \\
\text { jams) }\end{array}$ \\
\hline
\end{tabular}

Source: own research.

The most frequently mentioned advantages of carsharing services included: speed and convenience of transportation, as well as high availability of vehicles offered by various service providers. The respondents also indicated free parking in paid parking zones and the possibility of choosing a car from a variety of new models and car brands. The surveyed also appreciated the predictability of costs and the ability to estimate the trip fare in advance. This results from transparent price lists as well as rates by the kilometer or minute provided by carsharing organizations. Several respondents indicated that carsharing can replace private car ownership and eliminate the costs it generates. On the other hand, there were respondents who declared that carsharing provides 
the possibility to use a car in an emergency situation, e.g. when their private car is out of order.

The disadvantages of carsharing indicated by the respondents included: the limited size of zones where vehicles can be picked up and dropped off and occasional unavailability of free vehicles at the expected location or time. However, despite the continuous development of this type of services and the expansion of vehicle fleets, carsharing companies recommend booking a vehicle when a person intends to use it. In most cases, after booking in advance, the user receives a free 15 minutes to start the trip. The respondents also pointed out that vehicles offered in carsharing schemes are in the lowest trim levels, complained about insufficient number of parking zones dedicated to shared cars, as well as restrictions on the transport of animals which can only be driven in special transport crates. The restrictions on the transport of animals may be introduced for safety reasons, but also to ensure that the vehicle meets the standards of cleanness. The respondents also indicated that some instructions for starting and ending the car rental as well as opening, starting or closing a vehicle are confusing. Other negative opinions concerned the high amount of the deposit and the cost of using shared cars during the traffic peak period or in traffic jams. The solution to this problem may be the increasingly popular tariffs for carsharing services that do not take into account the driving time, but include a starting fee and a higher rate by the kilometer. Some service providers allow users to choose the tariff option.

The respondents were also asked to indicate those aspects of carsharing services which, in their opinion, should be changed or improved. The answers included equipping cars with parking sensors, improving the operating instructions and extending the zones where the vehicle can be picked up and dropped off. 


\section{Conclusions}

In recent years, the sharing services in the field of passenger transport have been developing dynamically. This includes carsharing schemes introduced in Poland in 2016. Since then, many new initiatives and improvements to the existing systems have been implemented, thanks to which carsharing services are now considered a mobility service which is complementary or alternative to public transport, taxi services or privately owned cars.

The reason for the growing popularity of this type of service may be the change in people's awareness resulting in new mobility patterns. This is especially the case in large cities, where high population density and limited capacity of the urban public space result, inter alia, in problems with finding parking spaces. In addition, car parks situated in the city center are usually covered by paid parking zones. As a result, some people may no longer feel the need to own and maintain a private car all year round especially if they use it only occasionally. For them, what counts is the access to a vehicle when it is actually needed. It is possible thanks to carsharing, often offering new models of cars of different brands and segments enabling every user to find a suitable car. Moreover, the increase in the use of carsharing services may reduce the number of cars in the city, as the same vehicle can be used by different people during the day. On the other hand, the fact that the vehicles offered by carsharing companies are mostly the latest models that meet the current exhaust emission standards makes them environmentally friendly. Some of them are electric or hybrid vehicles, which significantly reduces the emission of harmful substances into the atmosphere. The above-mentioned factors have a decisive impact on the air quality in the city.

The use of carsharing services in Poland is at a moderate level. $27 \%$ of respondents declared that they use shared cars, which means that so far these services are still a niche proposition. Despite the high availability of cars in car sharing, only $15 \%$ of carsharing users travel several times a week.

The average monthly expenses for carsharing services declared by people using this type of services do not exceed PLN 50. This range was declared by as many as $53 \%$ of respondents, while the trip duration in a shared car is usually within the range of 15-30 minutes. 
Carsharing is a modern way of getting around the city using advanced technologies and contributing to its sustainable development. It combines the convenience of traveling with the possibility to reach the destination directly and by an environmentally friendly means of transport. However, carsharing services still remain a niche mobility option in the city as still a relatively small percentage of the respondents use this type of service. Those who actually use shared cars usually taker short distance trips lasting several dozen minutes, and their budget expenses for this type of transport are relatively low. 


\section{REFERENCES}

AppStore. (2021). FREE NOW (mytaxi). Retrieved (28.01.2021) from https://apps. apple.com/pl/app/free-now-mytaxi/id357852748?l=pl.

Becker H., Ciari F. i Axhausen K. (2015). Comparing Car-Sharing Shemes in Switzerland: User Groups and Usage Patterns. 16th Swiss Transport Research Conference. Retrieved (27.12.2020) from https://ethz.ch/content/dam/ethz/special-interest/ baug/ivt/ivt-dam/vpl/reports/1101-1200/ab1155.pdf.

BusinessInsider. (2020). Uber i Bolt będa jeździć jako taxi, ale sa problemy. Retrieved (24.01.2021) from https://businessinsider.com.pl/wiadomosci/uber-i-bolt-bedajezdzic-jako-taxi/hf9xzet.

Felson, M., Spaeth, J. L. (1978). Community structure and collaborative consumption: A routine activity approach, American Behavioral Scientist, 21(4), pp. 614-624.

FreeNow. (2021). O nas. Retrieved (28.01.2021) from https://free-now.com/pl/o-nas/ Janczewski, J. (2015). Wynajem jako forma wspótużytkowania samochodów. Wybrane kwestie, Zarządzanie Innowacyjne w Gospodarce i Biznesie 2 (21), pp. 86-101.

Kauf, S. (2018). Ekonomia współdzielenia (sharing economy) jako narzędzie kreowania smart city. Zeszyty Naukowe Politechniki Śląskiej Seria: Organizacja i Zarządzanie 120, pp. 141-151.

Kubera, M. (2018). Geneza i rozwój carsharingu w Polsce. Zeszyty Naukowe Politechniki Częstochowskiej Zarządzanie 31, pp. 119-133.

Larisch, R. (2014). Car Sharing. Biblioteka Źródłowa Energetyki Prosumenckiej. Retrieved (22.12.2020) from https://ppte2050.pl/platforma/bzep/static/uploads/ LARISCH_Romuald_-_Car_Sharing.pdf.

Magazyn Kaszuby. (2019). Jaka jest historia nowojorskich taksówek? Retrieved (23.01.2021) from http://magazynkaszuby.pl/2019/01/historia-nowojorskich-taksowek/

Malinowski, B. (2016). Czym naprawde jest sharing economy?. Retrieved (04.12.2020) from https://wethecrowd.pl/czym-jest-sharing-economy.

Matofska, B. (2016). What is the Sharing Economy? Retrieved (03.12.2020) from https:// www.thepeoplewhoshare.com/blog/what-sharing-economy.

Mazur, J., Włoch, R., Śledziewska, K. (2018). Taksówkarz - cyfrowy przedsiębiorca. Raport DELab UW, Retrieved (23.01.2021) from https://www.delab.uw.edu.pl/ wp-content/uploads/2020/08/Raport_Cyfrowi_taksowkarze_DELabUW.pdf.

Michalski, K., Bednarz, P., Popiel, J. (2019). Carsharing jako forma logistyki współdzielenia w mieście. Turystyka i Rozwój Regionalny 12, pp. 65-75.

Olejniczak, M., Mendakiewicz, A. (2018). Analiza wykorzystania system car-sharing $i$ jednoosobowych samochodów elektrycznych $w$ transporcie miejskim. w: U. Motowidlak, D. Wronkowski, A. Reńda (Eds.), Różne oblicza logistyki. Zbiór prac studentów (pp. 191-200), Łódź: Wydawnictwo Uniwersytetu Łódzkiego. 
Poniatowska-Jaksch, M. (2016). Modele biznesu w sharing economy, In: M. PoniatowskaJaksch, R. Sobiecki (Eds.), Sharing economy (ekonomia współdzielenia) (pp. 55-68), Warszawa: Oficyna Wydawnicza SGH.

PwC. (2015). The Sharing Economy. Consumer Intelligence Series. Retrieved (10.12.2021) from https://www.pwc.com/us/en/technology/publications/assets/pwc-consumer-intelligence-series-the-sharing-economy.pdf.

Shaheen, S., Sperling, D., Wagner, C. (1998). Carsharing in Europe and North America: Past, Present and Future. Transportation Quarterly 52 (3), pp. 35-52.

Sieńko, A. (2019). Nowa nazwa, stare problem. Mytaxi zmienia się we FreeNow, ale spór z taksówkarzami się tli. Retrieved (28.01.2021) from https://spidersweb.pl/ bizblog/mytaxi-freenow-konflikt-kierowcy.

STARS. (2018). Car sharing in Europe: a multidimensional classification and inventory. Retrieved (26.12.2021) from http://stars-h2020.eu/wp-content/uploads/2019/06/ STARS-D2.1.pdf.

Statista.com. (2020). Number of coworking spaces worldwide from 2005 to 2020. Retrieved (13.12.2020) from https://www.statista.com/statistics/554273/number-of-coworking-spaces-worldwide.

Stępnicka, N. (2018). Globalny, glokalny czy grobalny? - przypadek Uber Technologies, Inc. Zeszyty Naukowe Politechniki Śląskiej Seria: Organizacja i Zarządzanie 123, pp. 489-499.

Sylwestrzak, D. (2018). Klasyczne przewozy taksówkowe kontra Uber. Gdańskie Studia Prawnicze, XXXIX, pp. 135-148.

Uber. (2021). Miasta. Retrieved (28.01.2021) from https://www.uber.com/global/pl/ cities.

Weill, P., Vitale, M.R.(2001). Place to space, migrating to ebusiness models, Harvard Business School Press, Boston.

Wework.com. (2020). Retrieved (13.12.2020) from https://www.wework.com/pl-PL Zgiep Ł., (2014). Sharing economy jako ekonomia przyszłości. Myśl Ekonomiczna i Polityczna 4 (470), pp. 193-205.

Ziobrowska, J. (2017). Sharing economy jako nowy trend konsumencki. In: U. KalinaPrasznic (Ed.), Własność w prawie i gospodarce (pp. 261-269), Wrocław: E-Wydawnictwo. Prawnicza i Ekonomiczna Biblioteka Cyfrowa. Wydział Prawa, Administracji i Ekonomii Uniwersytetu Wrocławskiego. 
